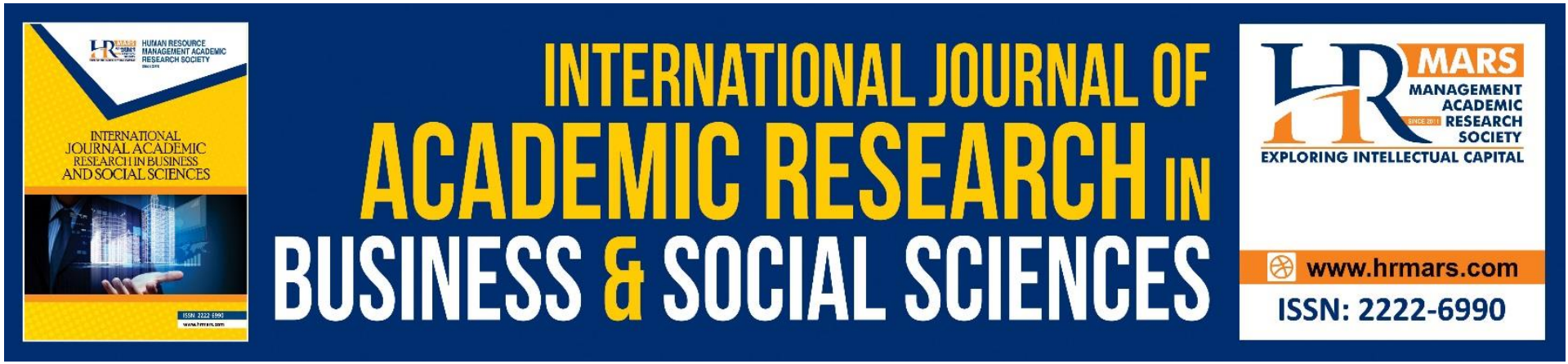

\title{
Farmer's Economic Change after Participating Vegetable Cultivation Using Solar Cell Supported by Private Sector
}

Krailert Taweekul

To Link this Article: http://dx.doi.org/10.6007/IJARBSS/v10-i11/8182

DOI:10.6007/IJARBSS/v10-i11/8182

Received: 08 October 2020, Revised: 28 October 2020, Accepted: 08 November 2020

Published Online: 23 November 2020

In-Text Citation: (Taweekul, 2020)

To Cite this Article: Taweekul, K. (2020). Farmer's Economic Change after Participating Vegetable Cultivation Using Solar Cell Supported by Private Sector. International Journal of Academic Research in Business and Social Sciences. 10(11), 1076-1083.

Copyright: (c) 2020 The Author(s)

Published by Human Resource Management Academic Research Society (www.hrmars.com)

This article is published under the Creative Commons Attribution (CC BY 4.0) license. Anyone may reproduce, distribute, translate and create derivative works of this article (for both commercial and non-commercial purposes), subject to full attribution to the original publication and authors. The full terms of this license may be seen at: http://creativecommons.org/licences/by/4.0/legalcode

Vol. 10, No. 11, 2020, Pg. 1076 - 1083

Full Terms \& Conditions of access and use can be found at http://hrmars.com/index.php/pages/detail/publication-ethics 


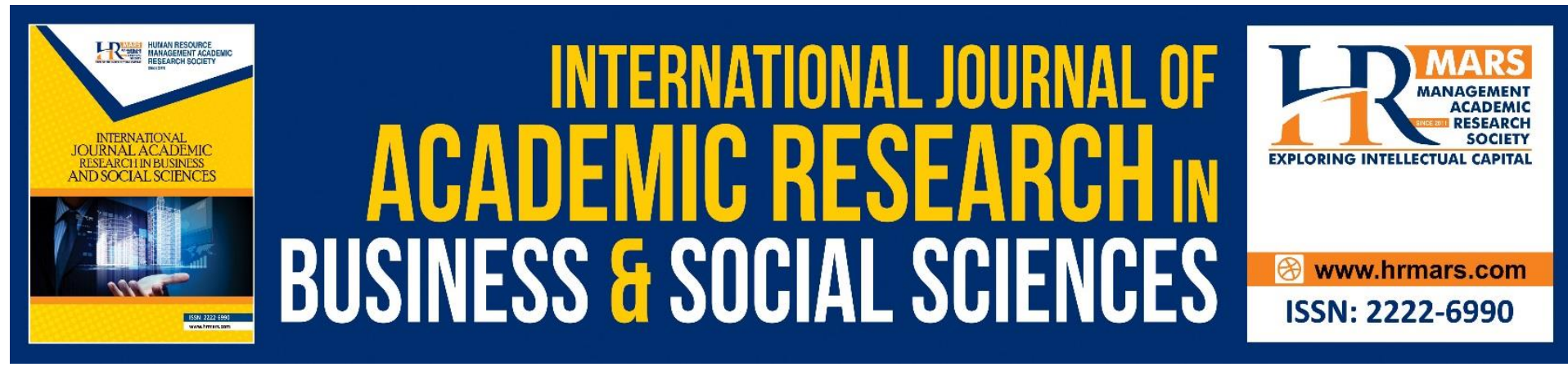

\title{
Farmer's Economic Change after Participating Vegetable Cultivation Using Solar Cell Supported by Private Sector
}

\author{
Krailert Taweekul \\ Agriculture Extension and Agricultural System, Faculty of Agriculture, Khon Kaen University, \\ Thailand.
}

\begin{abstract}
The paper examines: 1) utilization solar cell system for water supply and irrigation for vegetable cultivation, 2 ) the farmer's economic change after participating the project and 3 ) the model of promoting organizations involved the project for sustainable development. Questionnaires and focus group had been used for collecting data. Four villages in Khon Kaen province, Northeast Thailand were study area and 135 farmers had been interviewed. Research period was July 2017-June 2018. Research found the water supply system for vegetable cultivation consisted of water pond, solar cell, submersible pump, water tank, water pipe and water meter. Before joining the project, water supply used electricity to pump water. Water costed 5 bath/cubic meter, after joining the project, water costed 2 bath/cubic meter. 135 farmers in 4 villages participated cultivated free-chemically vegetable occupied 100-150 square meters per member. They gained annual income from vegetable cultivation 26,563 baht and totally 3,586,758 bath/ year, while project cost for building water system was $3,238,000$ bath. The research also found that a developing model of promoting organizations involved in solar cell project was four main organizations involved: 1) Private sector and NGO : Coca Cola and Population and Community Development Association, 2) Markets : Tesco lotus department store, local markets 3) Academic institution: Khon Kaen University and 4) People organization: Farmer group.
\end{abstract}

Keywords: Solar Cell, Farmers, Income, Model.

\section{Introduction}

Rural development is very important for improving the quality of life of grassroots groups in Thailand. The aim of rural developments is to improve the economic and social livelihood of special target groups, in particular the poor in rural areas. In the past, the traditional thinking had been that only government must attend to the welfare of villagers. However, at present, the role of Non Government Organisations (NGOs) and public sectors in Thailand has dramatically increased and become significantly established.

Rural development in Thailand was facing a difficult task due two main reasons: 1 ) its image as a prosperous country has led donor agencies to categorise Thailand as a nonrecipient and 2) Thailand's economic is headed recession (Parasak, 2019), this has meant the governmental budget for various developing programmes has declined. Moreover, the main 
problem that Thai NGOs currently face is rapidly diminishing support from international donor agencies. Thus, to find out partners joining development projects in the country such as private sectors is very important.

\section{Significance of NGO and Private Sector in Rural Development Program}

NGOs tend to work with and have better access to grassroots groups and villager organisations who lack opportunity in terns of standard of living in society. NGOs usually transfer their appropriate skills to their target groups. They can also contribute the needed innovation, flexibility and dedication, which are necessary to the rural development activities. By doing this, NGOs are well placed to bring the marginalized and the poor within the mainstream of development. NGOs fundamentally still use the villager participatory approach in their development process.

NGOs tended to have various approaches to rural development programmes. The development agencies attempt to design an approach that will create an appropriate model depending on the circumstances. Actually, the models can help NGOs to decide where they can make the greatest contribution in rural communities. IDFC (2013); Panteli et al (2013) mentioned four main approaches adopted by NGOs: 1) relief and welfare, 2) community development, 3) sustainable development, and 4) villager movements.

Development programmes have both advantages and disadvantages to the country. Undoubtedly, the remarkable economic growth from development programmes has resulted in various social changes. The economic and social development progarmmes are having a substantial impact on many issues related to demography and health, education, urbanization, natural resources, and the response to change

The concept of promoting private company involvement in rural development in Thailand has been created and developed by the PDA since 1986. Demonstrate that the basic idea is to mobilize the relatively untapped private companies to participate actively in rural development, especially to help develop the business skills of villages, create new jobs, and provide market opportunities. As Kaplan and Herforth (2019) mentioned since the mid-1990s, the importance of the private sector as partner in development co-operation has been growing. Furthermore, the private sector should be incentivized as they serve as information aggregators and render post-production service to farmers (Dey, 2000). Public-private partnerships (PPPs) are being promoted as important institutional mechanism for gaining access to additional resource, sharing risks and adding other constraints in pursuit of sustainable and inclusive development (Rankin and Santacoloma, 2013).

NGOs are effective in promoting social development, but in general, they lack business knowledge, skill, and experience to transfer this to the villagers. Neither NGOs nor Government Organizations (GOs) have well developed business skills in organization, production, financial management, and marketing to provide for target groups. However, villages do need these skills to earn cash incomes. Furthermore, NGOs have small staff numbers hence they can only cover a small percentage of the population. In contrast, government agencies have large number of officers but they still lack the experience to provide the business skills for the rural villager. 
Therefore, there is a need for NGOs and GOs to find a partner capable for providing and transferring business and academic skills to the poor in villages. Particularly, NGOs can play an important role by persuading the private companies sponsoring the villages, and harnessing of their business experiences to village needs. This was an innovative approach to a rural development programmers' in the country.

\section{Objectives}

This paper examines: 1) utilization solar cell system for small irrigation management system, 2) the economic of farmer change after farmers participating the project and 3) the model of promoting organizations involved the project for sustainable development.

\section{Research Methods}

This research was carried out during July 2017 - June 2018 since the water using solar cell just finished and donor needed to know the result for implement new project and farmers also cultivated vegetable more than one year. Four villages: Nongya, Nonghee, Hinhow and Nongpho villages located Khon Kaen province had been selected to be study area and 135 farmers were interviewed including 49 farmers participated focus group.

\section{Results and Discussion}

\subsection{Utilization solar cell system for water supple and irrigation management}

The small Irrigation using solar cell as source of energy to pump water from pond. This was a village-based irrigation system for the purpose of year - round, intensive production of high - value crops, in particular of vegetables.

The water system consisted a physical infrastructure to utilize existing water resource using solar cell system for irrigation as well as related organization structure to manage small irrigation system as shown in Figure 1.

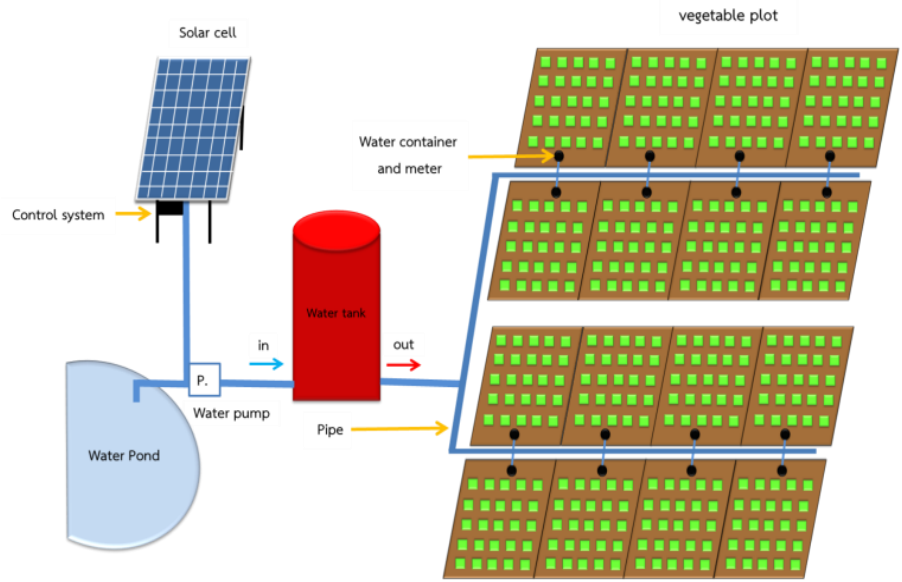

Figure 1 : water system using solar cell for vegetable cultivation

The study found that the small irrigation system consisted of four main components:

i) A water pump: 1.5 Horse power ( $\mathrm{Hp}$ ), needs 1,500 watts and control system to extract water from pond, it was deep 5 meters,

ii) holding tanks to store the water: capacity 20,000 liters.

iii) a network of pipes with taps and small tank reservoirs at each member outlet, and

iv) solar panel : 9 panels producing electricity 2,700 watts to be source of energy. 
The small irrigation systems in four villages were managed by Village Water Management Committees (VWMC) specifically set up for this purpose. The 11 persons was elected to be committees by the assembly of members and had the specific task of collecting water fees from members, executing system maintenance works as well as assisting members on agricultural and marketing matters. Interestingly, woman must be represented to at least 50 $\%$ of the member committees.

This provided the opportunity for women in rural area to manage their resources and took place to manage the groups.

Membership in the project was voluntary and principle opened to all village residents. The project targets particularly was the poor villagers first and encourages their participation. Each member had to make both financial and in - kind contributions to the project. With regard to the financial contribution, they commit themselves to pay for water cost 2 bath per cubic meter, on a monthly basis, based on how much water was used. Members also contributed with their own labour to help in the system construction. These local contributions ensured that the project addressed member needs and was economically viable. More important, water system using solar cell had been built one month, group member spent labour, private sector provided the budget while NGO supported the technician.

\section{The Economic Change after Farmers Participated the Project}

Each farmer who participated the project, usually they cultivated the free - chemically vegetable, has gained income top up from basic crops; rice, cassava and sugarcane. It can be seen that income from joining the project by cultivating the vegetable approximately $29.75 \%$ of total farm income. This mean after participating the small irrigation by using solar cell project farmers earned extra income than the past.

Table 1 : Income from vegetable cultivation after joining project (bath/farmer/year)

\begin{tabular}{|c|c|c|c|c|c|}
\hline Village & $\begin{array}{c}\text { No. of } \\
\text { number }\end{array}$ & $\begin{array}{c}\text { Highest } \\
\text { income } \\
\text { (bath) }\end{array}$ & $\begin{array}{c}\text { Lowest } \\
\text { income } \\
\text { (bath) }\end{array}$ & $\begin{array}{c}\text { Average } \\
\text { income } \\
\text { (bath) }\end{array}$ & $\begin{array}{c}\text { Total } \\
\text { income } \\
\text { (bath) }\end{array}$ \\
\hline 1. Nonghee & 31 & 68,134 & 17,830 & 25,170 & 782,674 \\
\hline 2. Nongpho & 32 & 64,730 & 11,152 & 27,136 & 870,756 \\
\hline 3. Hinhow & 28 & 65,117 & 8,906 & 27,819 & 781,336 \\
\hline 4. Nongya & 44 & 63,063 & 13,268 & 26,127 & $1,451,992$ \\
\hline \multirow{2}{*}{ Total } & \multirow{2}{*}{135} & average & average & \multirow{2}{*}{26,563} & $3,886,758$ \\
\cline { 3 - 4 } & & 65,261 & 12,789 & & \\
\hline
\end{tabular}

Total 135 farmers have joint the project by cultivating the free-chemically vegetables. They gained money extra from cultivated basic crops: rice, cassava and sugarcane. Table 1 illustrated all farmers in four village earned gained average income 26,563 baht per year per member while they gained income from the same activity approximately 16,340 bath/farmer/year before participating project. The Table 1 also showed that all farmers gained 3,586,000 baht per year from free-chemically vegetable production, while Coca Cola company (known as Coca Cola Foundation) had supported 3,238,000 baht to set up the water using solar cell system. It can be seen that $B / C$ ratio was 1.11 , this showed farmers gained money more than investment cost in one year. 


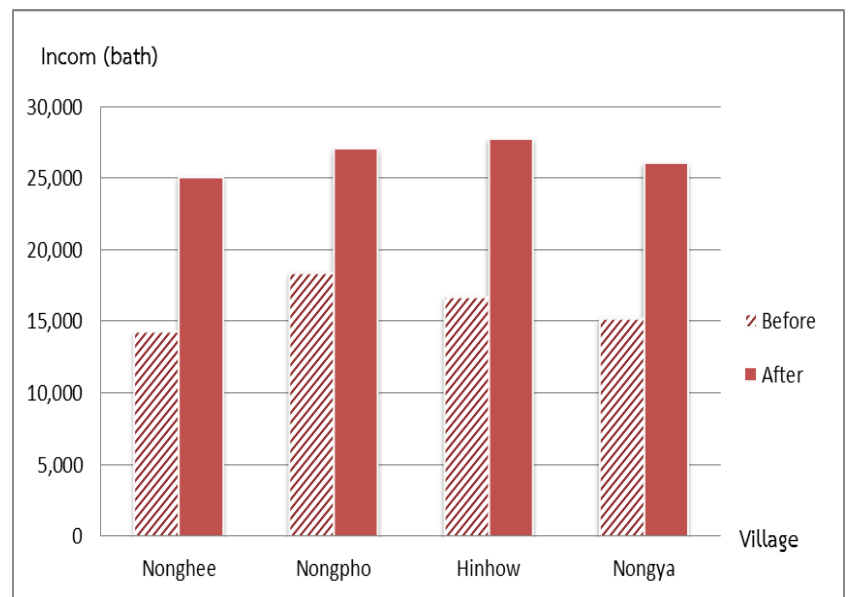

Figure 2: Comparison income from vegetable before and after joining project (bath/farmer/year)

Figure 2 illustrated the income of farmers had been changed before and after participating water solar cell project. Farmer in all four villages gained income from freechemically cultivation higher than before participating project approximately 10,223 bah/farmer/year about $62.56 \%$ increased. This also showed that free-chemically vegetable was easy for farmers to sell in markets and to get good price as Suindramedhi, Tokuda, and Ehara (2016) found that organic vegetable was target vegetable of people both in Thailand and Japan this led to big market.

\section{The Model of Promoting Organizations Involved in Water Development.}

Farmers had learnt sufficient water use and small irrigation management after participating project since there were various organization getting involved. The projects provided opportunity for farmer with participating approach every step since planning, constructing, operating, selling managing and ownership. These small irrigation systems belonged to farmer groups after construction finished. Especially, the project stimulated them to learn how to repair all equipment. This was one factor leading the projects sustainability. Another factor to lead sustainable project was the markets both in the local markets and outside the communities such as department stores, agro processing factories. Research also investigated a developing model of promoting organizations involved the project, four main organizations involved in the solar cell project: 1) Private sectors: Coca Cola company and NGO: Population and Community Development Association(PDA), 2) Markets : Tesco lotus department store, Tops supermarket, Local markets, 3) Academic institution: Khon Kaen University and 4) Farmer groups. The connection and relation to implement project and built up the network to be a model for development was shown in Figure 3 and Table 2 below. 


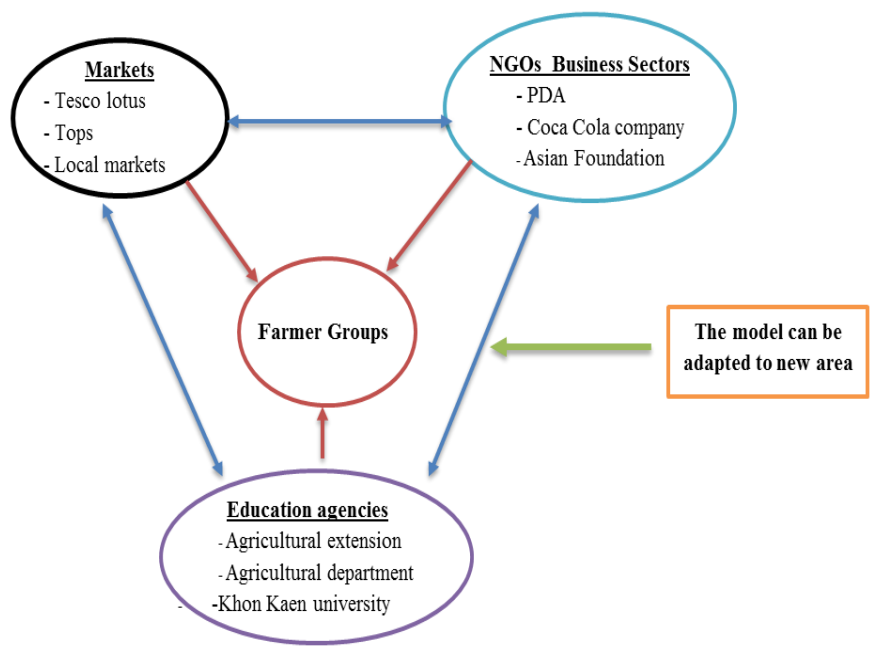

Figure 3: A developing model of organizations getting involved in network building to move activities.

Table 2 : Responsibilities of organizations involved in a development model

\begin{tabular}{|c|c|c|}
\hline No. & organizations & Responsibilities \\
\hline 1 & $\begin{array}{l}\text { Private sectors: Coca Cola } \\
\text { company and NGO (PDA) } \\
\text { ASEAN Foundation }\end{array}$ & $\begin{array}{l}\text {-support budget -support training } \\
\text {-technical for construction system } \\
\text {-follow up activities -Community } \\
\text { preparation }\end{array}$ \\
\hline 2 & $\begin{array}{l}\text { Markets : Tesco lotus } \\
\text { depart, Tops supermarket, } \\
\text { Local markets }\end{array}$ & $\begin{array}{l}\text {-place for selling vegetables } \\
\text {-buying vegetables } \\
\text {-packaging design } \\
\text {-marketing plan }\end{array}$ \\
\hline 3 & $\begin{array}{l}\text { Academic institution: Khon } \\
\text { Kaen University }\end{array}$ & $\begin{array}{l}\text {-training on vegetable cultivation } \\
\text { - GAP product } \\
\text {-group management }\end{array}$ \\
\hline 4 & $\frac{\text { People organization: }}{\text { farmer groups }}$ & $\begin{array}{l}\text {-member preparation } \\
\text {-operation system and cultivate } \\
\text { vegetables }\end{array}$ \\
\hline
\end{tabular}

Farmers in four groups implemented activities follow the Sufficient Economic Philosophy that stresses the middle path as an overriding principle for appropriate conduct. The three components are reasonableness (or wisdom), moderation, and prudence. Two essential underlying conditions are knowledge and morality have been modified by farmers. They leant how reduce cost, how to increase income, how to work together and support each other including how to find opportunity, this same as Phuripanyo (2016) founded that farmers implemented activities by following Sufficient Economic Philosophy led them gaining and sharing knowledge for improve their activities.

\section{Conclusion}

1) The farmer group had an important role to promote and produce chemically free vegetable by stimulating the 135 members learning from each other. 
2) Farmers cultivated the free chemically vegetable production, has gained income top up from basic crops; rice, cassava and sugarcane. It can be seen that income from joining the project by cultivating the free-chemically vegetable approximately $29.75 \%$ of total farm income.

3) Total 135 farmers gained 3,586,758 baht per year, while Coca Cola company had sponsored $3,238,000$ baht to set up the small irrigation system. Farmers exactly gained money more than investment cost in one year.

4) The research also found that the developing model of promoting Private sectors, NGO, Farmer group and the University getting involved in solar cell project has been developed for sustainable development 1 model.

\section{Limitation and Recommendation}

1) During research period, some months had rain, this made farmer could nor cultivated vegetable and also rain drop destroyed vegetable leaf.

2) Farmers worked on rice farms thus it was difficult to meet them.

3) Greenhouse should be promoted to protect rain.

4) Many alternative energy technology should be promoted to farmers to reduced their cost from electricity and pretrial.

\section{References}

Dey, S. (2000). Private sector engagement in rural development. New Delhi. India.

Kaplan, M., and Herforth, N. (2019). The private sector and development co0-operation-two unequal partners in the promotion of agriculture. Rural 21 . Vol.53 No.1/2019

Parasak, C. (2019). Thailand's economic is headed for new recession. WIRE Southeast Asia. Bangkok. Thailand.

Panteli, P., Griva, E., \& Tsakiridou, E. (2013). Multilingualism in the Cypriot Educational System: A Record of Primary School Students' Views and Attitudes. Multilingual Academic Journal of Education and Social Sciences, 1(1), 19-38.

Phuripanyo, C. P. (2016). Rural Development Based on Sufficient Economy Philosophy. Journal of Buddist Education and Research. Vol. 2 No. 1 (January - June 2016)

Rankin, M., and Satacoloma. (2013). Agribusiness Public-Private: A country report of Thailand. FAO. Rome.

Suindramedhi, S., Tokuda, H., and Ehara, H. (2016). Rural Socio-economic development: A comparative study of Thailand and Japanese Excperience on Organic farming. GMSARN International Journal V.10 